\title{
$\alpha$-Glucosidase Inhibition by New Schiff Base Complexes of Zn(II)
}

\author{
Rie Miyazaki' ${ }^{1}$, Hiroyuki Yasui', Yutaka Yoshikawa ${ }^{1,2}$ \\ ${ }^{1}$ Department of Analytical and Bioinorganic Chemistry, Kyoto Pharmaceutical University, Kyoto, Japan \\ ${ }^{2}$ Department of Health, Sports, and Nutrition, Faculty of Health and Welfare, Kobe Women's University, \\ Hyogo, Japan \\ Email:yasui@mb.kyoto-phu.ac.jpand,y-yoshikawa@yg.kobe-wu.ac.jp
}

Received 30 December 2015; accepted 9 April 2016; published 12 April 2016

Copyright (C) 2016 by authors and Scientific Research Publishing Inc.

This work is licensed under the Creative Commons Attribution International License (CC BY). http://creativecommons.org/licenses/by/4.0/

(c) () Open Access

\begin{abstract}
There are many reports that divalent alkaline earth, first-row transition metals, and $\mathrm{Zn}$ (II) ions have $\alpha$-glucosidase inhibitory effects. $\mathrm{Cu}$ (II) and $\mathrm{Zn(II)}$ ions, in particular, have strong $\alpha$-glucosidase inhibitory effects. Several Schiff bases also display $\alpha$-glucosidase inhibitory effects. In this study, we focused on safe and highly effective complexes including $\mathrm{Zn}$ (II) ion. We prepared and characterized the $\mathrm{Zn}$ (II) complexes with four different Schiff bases ( $\mathrm{N}$-salicylidene- $\beta$-alanine ( $\mathrm{N}$ $\mathrm{s} \beta$ ), $\mathrm{N}$ - $\mathrm{N}^{\prime}$-bis (salicylidene) ethylenediamine ( $\mathrm{N}$-bsE), $\mathrm{N}, \mathrm{N}^{\prime}$-bis (salicylidene)-phenylenediamine ( $\mathrm{N}$ bsP), and 1-[(2-dimethylaminoethylimino) methyl]naphtholate (DMN)) and investigated their $\alpha$ glucosidase inhibitory effects in vitro, using $\alpha$-glycosidases from Saccharomyces sp. and rat small intestine, and in vivo, using a sucrose tolerance test. The $\mathrm{Zn}$ (II) complexes with DMN showed the highest in vitro and in vivo $\alpha$-glucosidase inhibitory effects in this study.
\end{abstract}

\section{Keywords}

$\alpha$-Glucosidase Inhibitory Effect, Zn(II) Complexes, Schiff Bases, Diabetes Mellitus

\section{Introduction}

In 2006, the World Health Organization predicted that the number of patients with type 2 diabetes mellitus in the world could increase to 360 million by 2030 [1]. Early detection and rapid cure are very important, because complications of diabetes such as nephropathy, retinopathy, and neuropathy are difficult to treat. Oral antidiabetic medicines have been used as one of the principle therapeutic methods to treat diabetes. $\alpha$-Glucosidase inhibitors comprise one class of oral antidiabetic medicines. As of 2013, three types of $\alpha$-glucosidase inhibitors, 
acarbose, voglibose, and miglitol, are used in medical practice (Figure 1). $\alpha$-Glucosidase is an enzyme that metabolizes disaccharides into monosaccharides in the small intestine. Inhibiting this enzyme delays the digestion and absorption of carbohydrates, which results in suppression of both postprandial hyperglycemia and excessive insulin secretion.

$\mathrm{Zn}(\mathrm{II})$ ion and their complexes also exhibit antidiabetic effects; therefore, a variety of studies have investigated their application to diabetes [2]-[4]. As one of the mechanisms of their antidiabetic effects, we discovered the possible involvement of a $\alpha$-glucosidase inhibitory ( $\alpha$-GI) effect in 2009 [5]. Moreover, to improve this effect of $\mathrm{Zn}$ (II) ion, various $\mathrm{Zn}$ (II) complexes have been synthesized [6]-[8]. Among them, we focus on Schiff bases (Scheme 1). Several Schiff bases exhibit $\alpha$-GI effects [9] [10], anti-inflammatory effects [11]-[13], antibacterial effects [13]-[17], anti-HIV effects [17], anti-convulsive effects [18] [19], and anti-tumor effects [20] by themselves. Furthermore, Schiff bases consist a large number of compounds; therefore, we can select the compounds that are easy to synthesize. By combining Zn(II) ion and Schiff bases, we anticipate a synergistic interaction of their antidiabetic effects.

In this study, we synthesize four Schiff base ligands: N-salicylidene- $\beta$-alanine $(\mathrm{N}-\mathrm{s} \beta)$ [21], N-N'-bis (salicylidene) ethylenediamine (N-bsE) [9], N, N'-bis(salicylidene)-phenylenediamine (N-bsP) [9], and 1-[(2-dimethylaminoethylimino) methyl]naphtholate (DMN) [22]; as well as their Zn(II) complexes: [N-s $\beta$-Zn], [N-bsE-Zn], [N-bsP-Zn], and $\left[\mathrm{Zn}_{2}\left\{(\mathrm{DMN})_{2} \mathrm{Cl}_{2}\right\}\right]$. We also evaluate the $\alpha$-GI effect of these complexes using both in vitro and in vivo experimental systems.

\section{Experimental Methods}

\subsection{Materials and Animals}

All reagents and solvents used in this study were of the highest commercially available grade and were used as obtained. $\left(\mathrm{CH}_{3} \mathrm{COO}\right)_{2} \mathrm{Zn} \cdot 2 \mathrm{H}_{2} \mathrm{O}, \mathrm{ZnCl}_{2}$, salicylaldehyde, $\beta$-alanine, ethylenediamine, 2-hydroxy-1-naphtaldehyde, $\mathrm{LiOH} \cdot \mathrm{H}_{2} \mathrm{O}$, HEPES, $\mathrm{NaOH}, \mathrm{KH}_{2} \mathrm{PO}_{4}$, dithiothreitol, $\alpha$-glucosidase (from Saccharomyces sp.), maltose, d(+)-glucose, powdered acacia, and a Glucose C-II Test kit were purchased from Wako Pure Chemical Industries (Osaka, Japan). O-phenylenediamine was purchased from Kanto Chemical Co., Inc. (Tokyo, Japan). N, N-dimethylethylenediamine was purchased from Tokyo Chemical Industry Co. (Tokyo, Japan). EDTA $2 \mathrm{Na} \cdot 2 \mathrm{H}_{2} \mathrm{O}$ and Triton X-100 were purchased from Nacalai Tesque, (Kyoto, Japan). Rat small intestine acetone powder was obtained from Sigma Chemical Co. (St. Louis, MO, USA). Twelve-week-old ddYmice, which are non-inbred mice maintained in a closed colony, were purchased from Shimizu Laboratory Supplies Co. (Kyoto, Japan). All the mice were maintained on a $12 \mathrm{~h}$ light/dark cycle in our temperature-controlled central animal facility for breeding under fixed condition. The animal study was approved by the Experimental Animal Research Committee at the Kyoto Pharmaceutical University (KPU) and was performed according to the Guidelines for Animal Experimentation.

\subsection{Synthesis of Four Ligands and Their $\mathrm{Zn}$ (II) Complexes}

We synthesized four Schiff base ligands and their Zn(II) complexes (Schemes 2-5). The syntheses of these ligands were performed as described in previous reports [9] [21] [22]. The intended Zn(II) complexes were readily

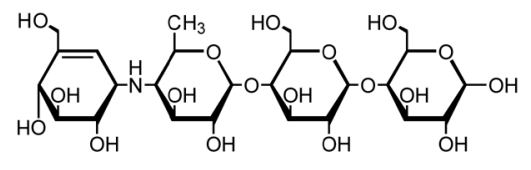

acarbose

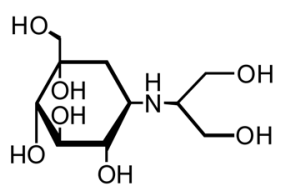

voglibose

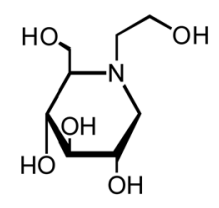

miglitol

Figure 1. Chemical structures of $\alpha$-glucosidase inhibitors.

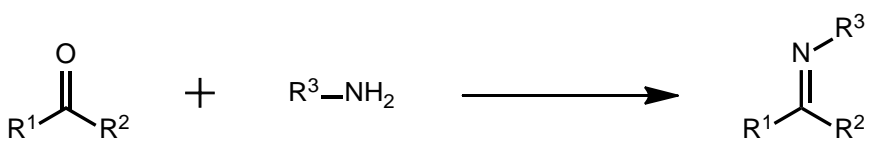

Scheme 1. Chemical structure of Schiff base. 

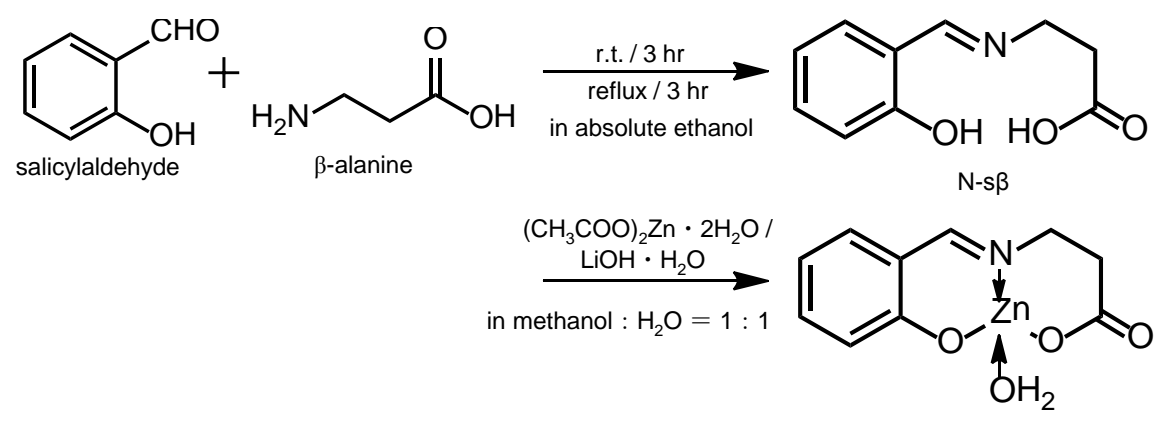

$[\mathrm{N}-\mathrm{s} \beta-\mathrm{Zn}]$

Scheme 2. Synthesis of N-s $\beta$ and [N-s $\beta-\mathrm{Zn}]$.

2

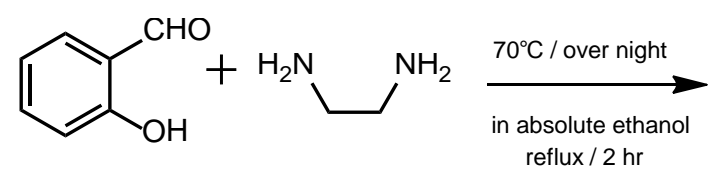

salicylaldehyde

ethylenediamine

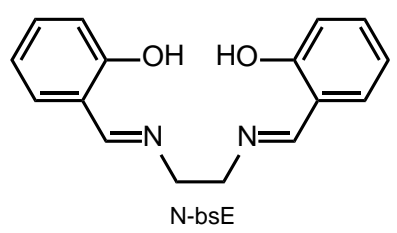

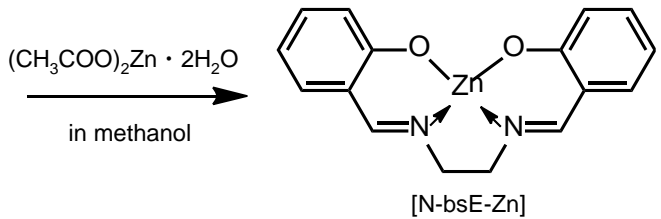

Scheme 3. Synthesis of N-bsE and [N-bsE-Zn].

2<smiles>Nc1ccccc1N</smiles>

salicylaldehyde

phenylenediamine<smiles>Oc1ccccc1/C=N/c1ccccc1/N=C/c1ccccc1O</smiles>

$\mathrm{N}-\mathrm{bsP}$

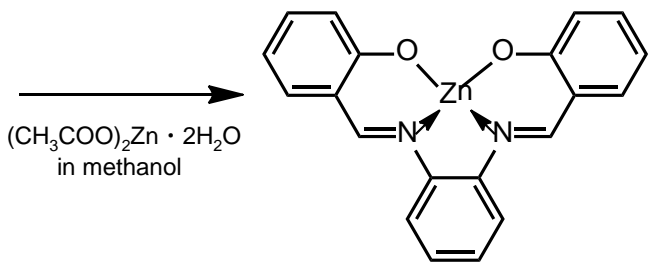

[N-bsP-Zn]

\section{Scheme 4. Synthesis of N-bsP and [N-bsP-Zn].}

prepared by adding $\left(\mathrm{CH}_{3} \mathrm{COO}\right)_{2} \mathrm{Zn} \cdot 2 \mathrm{H}_{2} \mathrm{O}$ or $\mathrm{ZnCl}_{2}$ to methanolic solutions of the various ligands at room temperature. The Zn(II) complexes were purified with water, methanol, and acetone to obtain [N-s $\beta$-Zn], [N-bsE-Zn], [N-bsP-Zn], and $\left[\mathrm{Zn}_{2}\left\{(\mathrm{DMN})_{2} \mathrm{Cl}_{2}\right\}\right]$.

\subsection{Preparation of $\alpha$-Glucosidase from Rat Small Intestine Acetone Powder}

The rat small intestine acetone powder was suspended in a $10 \mathrm{mM}$ sodium phosphate buffer (pH 6.8). The suspension was homogenized, sonicated for $30 \mathrm{~min}$ and followed by the addition of $2 \%$ Triton $\mathrm{X}$ buffer $(\mathrm{pH} 7.0)$ 


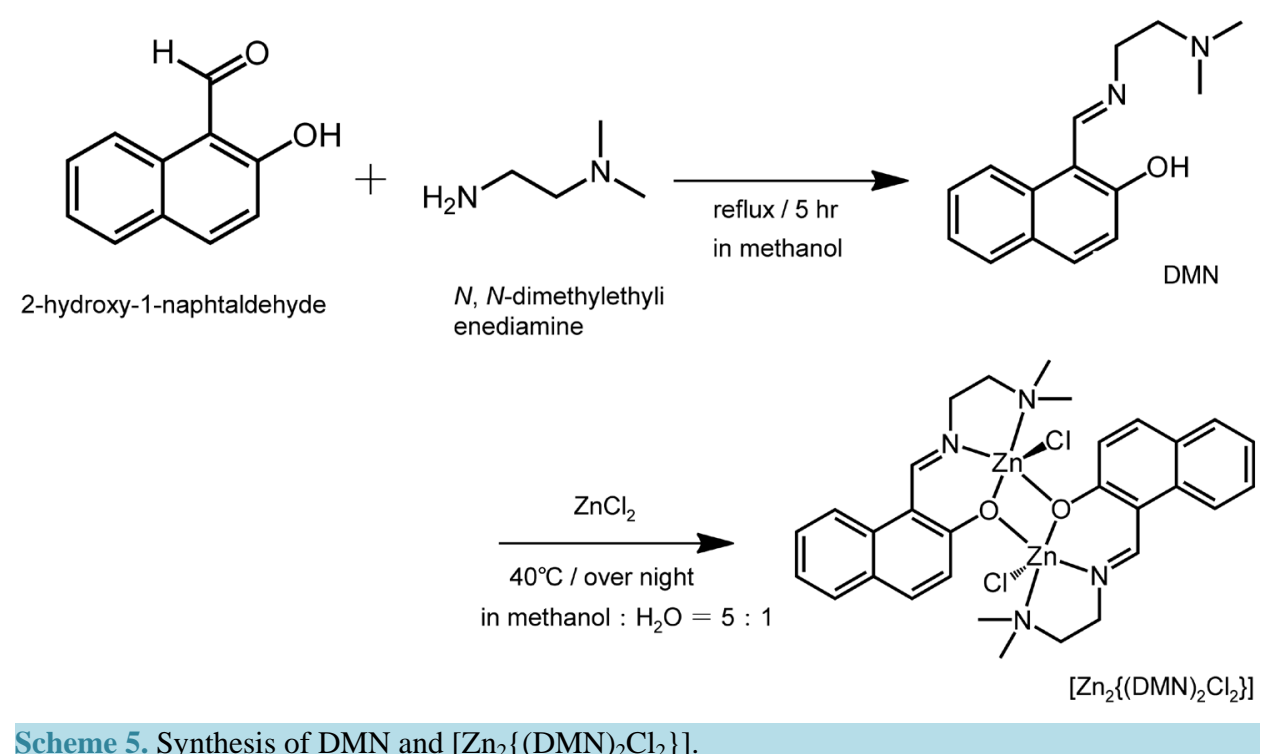

containing $3 \mathrm{mM}$ EDTA-2Na and $1 \mathrm{mM}$ dithiothreitol (DTT) in the ice bath and centrifugation for $60 \mathrm{~min}$ at $20,000 \mathrm{~g}\left(4^{\circ} \mathrm{C}\right)$. The supernatant was subjected to the ammonium sulfate precipitation. The precipitates were collected and dialyzed. The resulting solution was used for the assay.

\subsection{Inhibition of $\alpha$-Glucosidase in in Vitro}

Solutions of ligands or $\mathrm{Zn}$ (II) complexes at various concentrations were prepared, and their $\alpha$-glucosidase inhibitory effects were evaluated using a modified Dahlqvist method [23]. The substrate and test solution were mixed and incubated at $37^{\circ} \mathrm{C}$ for 5 min. A solution containing $\alpha$-glucosidase enzyme (5 unit/ml) from Saccharomyces sp. or rat small intestine was added continuously and incubated at $37^{\circ} \mathrm{C}$ for $1 \mathrm{~h}$. After incubation, the reactions were terminated by heating at $90^{\circ} \mathrm{C}$ for $5 \mathrm{~min}$. The glucose concentration was determined by using a Glucose C-II Test kit.

\subsection{Inhibition of $\alpha$-Glucosidase in in Vivo}

Twelve-week-old ddY mice were fasted for $6 \mathrm{~h}$ and were then orally administered one of the test solutions. After $30 \mathrm{~min}$, a 5\% acacia solution of maltose or glucose was orally administered [24]. Blood samples were obtained from the tail vein at $0,15,30,60$, and $90 \mathrm{~min}$. The blood glucose levels were measured using a glucose oxidase method (Glucocard; Arkray, Kyoto, Japan).

\subsection{Mode of $\alpha$-Glucosidase Inhibition by Zn(II) Complexes}

The mode of $\alpha$-glucosidase inhibition by $\left[\mathrm{Zn}_{2}\left\{(\mathrm{DMN})_{2} \mathrm{Cl}_{2}\right\}\right]$ was determined as reported elsewhere [25] [26]. The substrate and test solution were mixed and incubated at $37^{\circ} \mathrm{C}$ for $5 \mathrm{~min}$. Next, an $\alpha$-glucosidase enzyme solution was added and incubated at $37^{\circ} \mathrm{C}$ for $30 \mathrm{~min}$. After incubation, the reactions were terminated by heating at $90^{\circ} \mathrm{C}$ for $5 \mathrm{~min}$. The glucose concentration was determined by using a Glucose C-II Test kit. Substrate solutions containing sucrose at concentrations of 75, 150, and $300 \mathrm{mM}$ (Saccharomyces sp. experiment) and of 15, 30, and $60 \mathrm{mM}$ (rat small intestine experiment), and were prepared. [ $\left.\mathrm{Zn}_{2}\left\{(\mathrm{DMN})_{2} \mathrm{Cl}_{2}\right\}\right]$, which showed the highest activity in vitro, was used the IC50 value in in vitro study.

\subsection{Statistical Analysis}

All experimental data are expressed as the mean \pm standard derivation (SD). Statistical analyses of the in vitro data were performed using Student's t-test. Statistical analyses of the in vivo data were performed using one-way analysis of variance (ANOVA), followed by Dunnett multiple comparison post-hoc tests. Differences were considered to be statistically significant when p values were $<0.01$ or $<0.05$, as noted. 


\section{Results}

\subsection{Structural Characteristics}

Four Schiff base ligands and their Zn(II) complexes were characterized by several physicochemical methods. These data are shown in Table 1 and Table 2. For elemental analysis, both calculated and measured values of the percent concentration of $\mathrm{C}, \mathrm{H}$, and $\mathrm{N}$ were identical and within the estimated range of experimental error. In the IR spectra, we observed the frequencies due to the $v_{\mathrm{C}=\mathrm{N}}$ of $\mathrm{Zn}(\mathrm{II})$ complexes with four Schiff bases. And we observed the parent peak of these $\mathrm{Zn}$ (II) complexes in the Mass Spectra. When we measured NMR spectrometry, the $\mathrm{Zn}(\mathrm{II})$ ion induced the ${ }^{13} \mathrm{C}$ NMR chemical shift changes of the $\mathrm{N}$-s $\beta$, as shown in Table 2 . [N-s $\beta$-Zn] indicated a downfield shift $\Delta \delta=4.76,10.57,4.71$, for $\mathrm{C}(1), \mathrm{C}(5), \mathrm{C}(7)$, respectively. This results revealed that the $\mathrm{Zn}$ (II) ion binds exclusively with the $\mathrm{O}$ and $\mathrm{N}$ atoms of $\mathrm{N}-\mathrm{s} \beta$ (Table 2). From these data, we concluded that the structure of Zn(II) complexes with four Schiff bases were likely (Schemes 2-4).

\subsection{Inhibition of the $\alpha$-Glucosidase from Saccharomyces sp. in in Vitro}

In in vitro experiments involving yeast $\alpha$-glucosidase, the $\mathrm{Zn}(\mathrm{II})$ complexes exhibited $\alpha$-glucosidase inhibitory effects in the following order: $\left(\mathrm{CH}_{3} \mathrm{COO}\right)_{2} \mathrm{Zn} \cdot 2 \mathrm{H}_{2} \mathrm{O}(2.41 \pm 0.19 \mu \mathrm{M})>[\mathrm{N}-\mathrm{s} \beta$ - Zn $](2.89 \pm 0.91 \mu \mathrm{M})>[\mathrm{N}-$ bsE-Zn] $(3.10 \pm 0.74 \mu \mathrm{M})>$ zinc gluconate $(3.94 \pm 0.34 \mu \mathrm{M})>\left[\mathrm{Zn}_{2}\left\{(\mathrm{DMN})_{2} \mathrm{Cl}_{2}\right\}\right](4.06 \pm 0.45 \mu \mathrm{M})>[\mathrm{N}-$ bsP$\mathrm{Zn}](16.1 \pm 2.11 \mu \mathrm{M})$. On the other hand, the Schiff base ligands did not show $\alpha$-GI effects by themselves (Figure 2(a) and Figure 3(a)).

Table 1. Analytical data of four schiff base ligands and their Zn(II) compounds.

\begin{tabular}{|c|c|c|c|c|c|c|c|}
\hline \multirow{2}{*}{ Compound } & \multirow{2}{*}{$\begin{array}{l}\text { Yield } \\
(\%)\end{array}$} & \multicolumn{4}{|c|}{ Elemental analysis (\%) } & \multirow{2}{*}{$\begin{array}{c}\mathrm{IR}(\mathrm{KBr}) \\
\mathrm{C}=\mathrm{N}\left(\mathrm{cm}^{-1}\right)\end{array}$} & \multirow{2}{*}{$\begin{array}{c}\text { EI (+) MS } \\
\mathrm{m} / \mathrm{z}\end{array}$} \\
\hline & & & $\mathrm{C}$ & $\mathrm{H}$ & $\mathrm{N}$ & & \\
\hline $\mathrm{N}-\mathrm{s} \beta$ & 53 & $\begin{array}{l}\text { Found } \\
\text { Calc. }\end{array}$ & $\begin{array}{l}61.88 \\
62.16\end{array}$ & $\begin{array}{l}5.73 \\
5.74\end{array}$ & $\begin{array}{l}7.45 \\
7.25\end{array}$ & 1613 & $\begin{array}{c}193 \\
\left([\mathrm{M}]^{+}\right)\end{array}$ \\
\hline$[\mathrm{N}-\mathrm{s} \beta-\mathrm{Zn}]$ & 53 & $\begin{array}{l}\text { Found } \\
\text { Calc. }\end{array}$ & $\begin{array}{l}43.76 \\
43.74\end{array}$ & $\begin{array}{l}4.06 \\
4.04\end{array}$ & $\begin{array}{l}4.97 \\
5.10\end{array}$ & 1599 & - \\
\hline N-bsE & 77 & $\begin{array}{l}\text { Found } \\
\text { Calc. }\end{array}$ & $\begin{array}{l}71.82 \\
71.62\end{array}$ & $\begin{array}{l}6.06 \\
6.01\end{array}$ & $\begin{array}{l}10.47 \\
10.44\end{array}$ & 1578 & $\begin{array}{c}268 \\
\left([\mathrm{M}]^{+}\right)\end{array}$ \\
\hline [N-bsE-Zn] & 90 & $\begin{array}{l}\text { Found } \\
\text { Calc. }\end{array}$ & $\begin{array}{l}58.15 \\
57.93\end{array}$ & $\begin{array}{l}4.43 \\
4.25\end{array}$ & $\begin{array}{l}8.54 \\
8.45\end{array}$ & 1532 & $\begin{array}{c}330 \\
\left([\mathrm{M}-\mathrm{H}]^{+}\right)\end{array}$ \\
\hline N-bsP & 73 & $\begin{array}{l}\text { Found } \\
\text { Calc. }\end{array}$ & $\begin{array}{l}75.64 \\
75.93\end{array}$ & $\begin{array}{l}4.85 \\
5.10\end{array}$ & $\begin{array}{l}9.03 \\
8.86\end{array}$ & 1562 & $\begin{array}{c}316 \\
\left([\mathrm{M}]^{+}\right)\end{array}$ \\
\hline $\begin{array}{l}\text { [N-bsP-Zn] } \\
\left(+1.1 \mathrm{H}_{2} \mathrm{O}\right)\end{array}$ & 73 & $\begin{array}{l}\text { Found } \\
\text { Calc. }\end{array}$ & $\begin{array}{l}60.15 \\
60.12\end{array}$ & $\begin{array}{l}3.82 \\
4.09\end{array}$ & $\begin{array}{l}7.10 \\
7.01\end{array}$ & 1533 & $\begin{array}{c}378 \\
\left([\mathrm{M}-\mathrm{H}]^{+}\right)\end{array}$ \\
\hline DMN & 27 & $\begin{array}{l}\text { Found } \\
\text { Calc. }\end{array}$ & $\begin{array}{l}74.14 \\
74.35\end{array}$ & $\begin{array}{l}7.10 \\
7.49\end{array}$ & $\begin{array}{l}11.59 \\
11.56\end{array}$ & 1638 & $\begin{array}{c}242 \\
\left([\mathrm{M}]^{+}\right)\end{array}$ \\
\hline$\left[\mathrm{Zn}_{2}\left\{(\mathrm{DMN})_{2} \mathrm{Cl}_{2}\right\}\right]$ & 45 & $\begin{array}{l}\text { Found } \\
\text { Calc. }\end{array}$ & $\begin{array}{l}60.15 \\
60.12\end{array}$ & $\begin{array}{l}3.82 \\
4.09\end{array}$ & $\begin{array}{l}7.99 \\
8.19\end{array}$ & 1626 & $\begin{array}{c}685 \\
\left([\mathrm{M}+\mathrm{H}]^{+}, \mathrm{FAB}(+) \mathrm{MS}\right)\end{array}$ \\
\hline
\end{tabular}

Table $2 .{ }^{13} \mathrm{C}$ NMR data for $\mathrm{N}-\mathrm{s} \beta$ and $[\mathrm{N}-\mathrm{s} \beta-\mathrm{Zn}]$, in DMSO- $\mathrm{d}_{6}$ at room temperature.

\begin{tabular}{|c|c|c|c|c|c|c|c|c|c|c|}
\hline & \multicolumn{10}{|c|}{ Chemical shifts; $\delta / p p m$} \\
\hline & C-1 & $\mathrm{C}-2$ & C-3 & C-5 & C-6 & C-7 & C-8 & C-9 & C-10 & C-11 \\
\hline $\mathrm{N}-\mathrm{s} \beta$ & 174.32 & 36.57 & 55.57 & 162.08 & 117.95 & 167.94 & 119.98 & 133.14 & 120.02 & 133.81 \\
\hline$[\mathrm{N}-\mathrm{s} \beta-\mathrm{Zn}]$ & 179.08 & 37.89 & 59.07 & 172.65 & 115.37 & 172.65 & 119.95 & 135.46 & 123.60 & 137.51 \\
\hline$\Delta \delta$ & +4.76 & +1.32 & +3.50 & +10.57 & -2.58 & +4.71 & -0.03 & +2.32 & +3.58 & +3.70 \\
\hline & & 11 & & & & $10^{11}$ & 5 & 1 & & \\
\hline
\end{tabular}


(a)

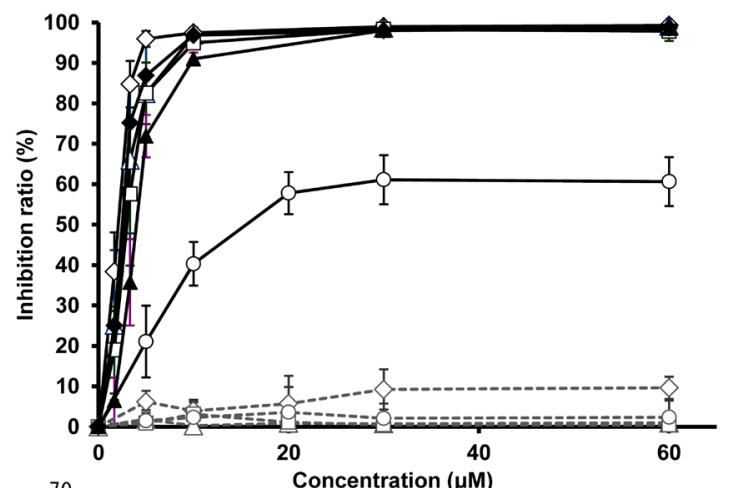

(b)

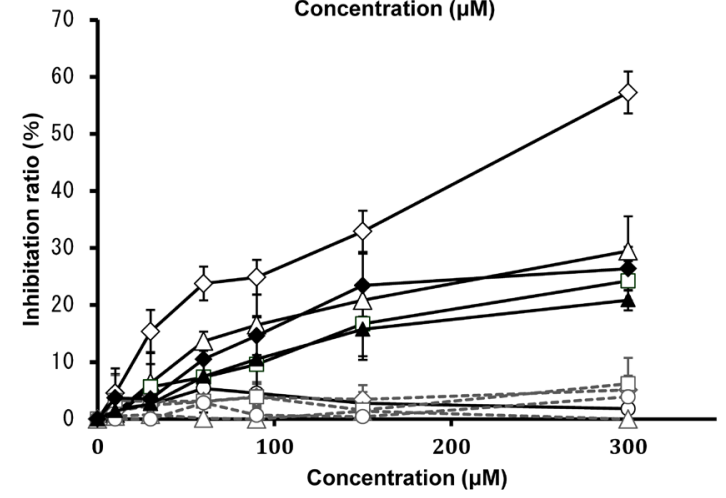

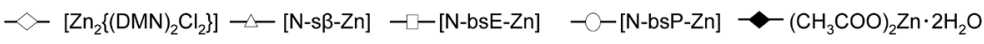

$$
\begin{aligned}
& -\diamond-\text { DMN } \\
& -\triangle-N-s \beta \quad-\square-N-b s E \\
& \text { - - - N-bsP } \\
& \leftarrow \text { Zinc gluconate }
\end{aligned}
$$

Figure 2. Inhibition of the $\alpha$-glucosidase activity ((a) yeast and (b) rat small intestine) by Zn(II) complexes and Schiff base ligands. Maltose $(0.1 \mathrm{M})$ was used as the substrate. Data are presented as the mean $\pm \mathrm{SD}(\mathrm{n}=3-4)$.
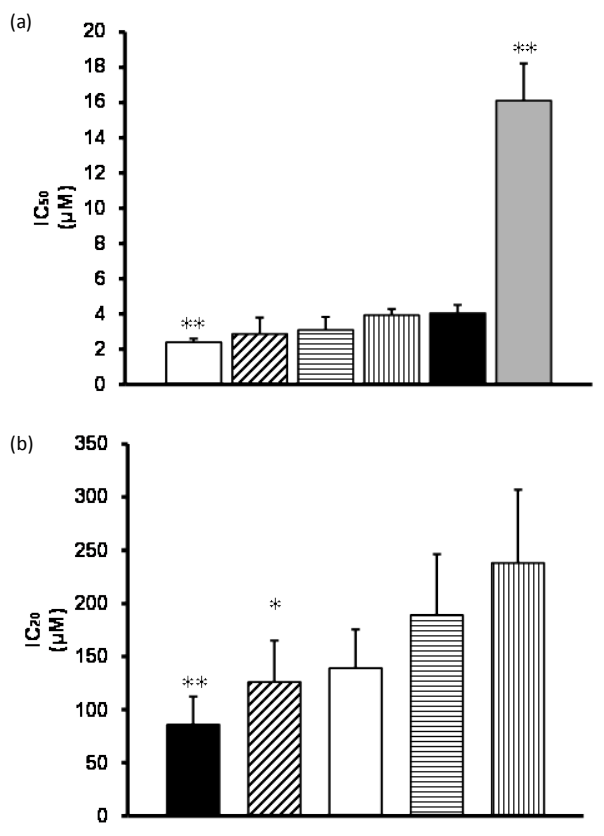

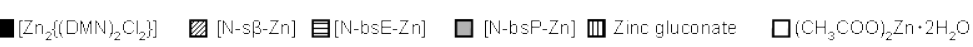

Figure 3. Estimated IC50 values of Zn(II) compounds and ligands for yeast $\alpha$-glucosidase (a). Estimated IC20 values of $\mathrm{Zn}$ (II) compounds and ligands for rat small intestinal $\alpha$-glucosidase (b). Maltose $(0.1 \mathrm{M})$ was used as the substrate. Data are presented as the mean \pm SD $(n=3-4)$. Significance: ${ }^{*} \mathrm{p}<0.05,{ }^{* *} \mathrm{p}<0.01$ vs. zinc gluconate. 


\subsection{Inhibition of the $\alpha$-Glucosidase from Rat Small Intestine in in Vitro}

In in vitro experiments involving rat intestinal $\alpha$-glucosidase, the $\mathrm{Zn}(\mathrm{II})$ complexes exhibited $\alpha$-glucosidase inhibitory effects in the following order: $\left[\mathrm{Zn}_{2}\left\{(\mathrm{DMN})_{2} \mathrm{Cl}_{2}\right\}\right](86.0 \pm 26.4 \mu \mathrm{M})>[\mathrm{N}$-s $\beta$ - Zn] $(126 \pm 39.1 \mu \mathrm{M})>$ $\left(\mathrm{CH}_{3} \mathrm{COO}\right)_{2} \mathrm{Zn} \cdot 2 \mathrm{H}_{2} \mathrm{O}(139 \pm 36.6 \mu \mathrm{M})>$ [N-bsE-Zn] $(189 \pm 57.3 \mu \mathrm{M})>$ zinc gluconate $(238 \pm 69.1 \mu \mathrm{M})$. In contrast, [N-bsP-Zn] and the Schiff base ligands did not show $\alpha$-GI effects by themselves (Figure 2(b) and Figure 3(b)).

\subsection{Oral Maltose and Glucose Tolerance Tests}

$\left[\mathrm{Zn}_{2}\left\{(\mathrm{DMN})_{2} \mathrm{Cl}_{2}\right\}\right.$, which showed a particularly high inhibitory effect against rat intestinal $\alpha$-glucosidase, and its Schiff base ligand, DMN, were selected for oral maltose and glucose tolerance testing. In the maltose tolerance test, the postprandial blood glucose levels in the $\left[\mathrm{Zn}_{2}\left\{(\mathrm{DMN})_{2} \mathrm{Cl}_{2}\right\}\right]$ group were significantly lower than those in control groups. In the glucose tolerance test, the postprandial blood glucose levels in the DMN group and the $\left(\mathrm{CH}_{3} \mathrm{COO}\right)_{2} \mathrm{Zn} \cdot 2 \mathrm{H}_{2} \mathrm{O}$ group were lower than those in the control groups. The values of the area under the curve (AUC) also showed similar transitions in each test (Figures 4(a)-(b) and Figures 5(a)-(b)).

\subsection{The Mode of $\alpha$-Glucosidase Inhibition}

The modes by which $\left[\mathrm{Zn}_{2}\left\{(\mathrm{DMN})_{2} \mathrm{Cl}_{2}\right\}\right]$ inhibited yeast and rat intestinal $\alpha$-glucosidase were studied. Lineweaver-Burk plots showed that $\left[\mathrm{Zn}_{2}\left\{(\mathrm{DMN})_{2} \mathrm{Cl}_{2}\right\}\right]$ acted as a non-competitive inhibitor of the yeast and rat intestinal $\alpha$-glucosidases (Figures 6(a)-(b)).

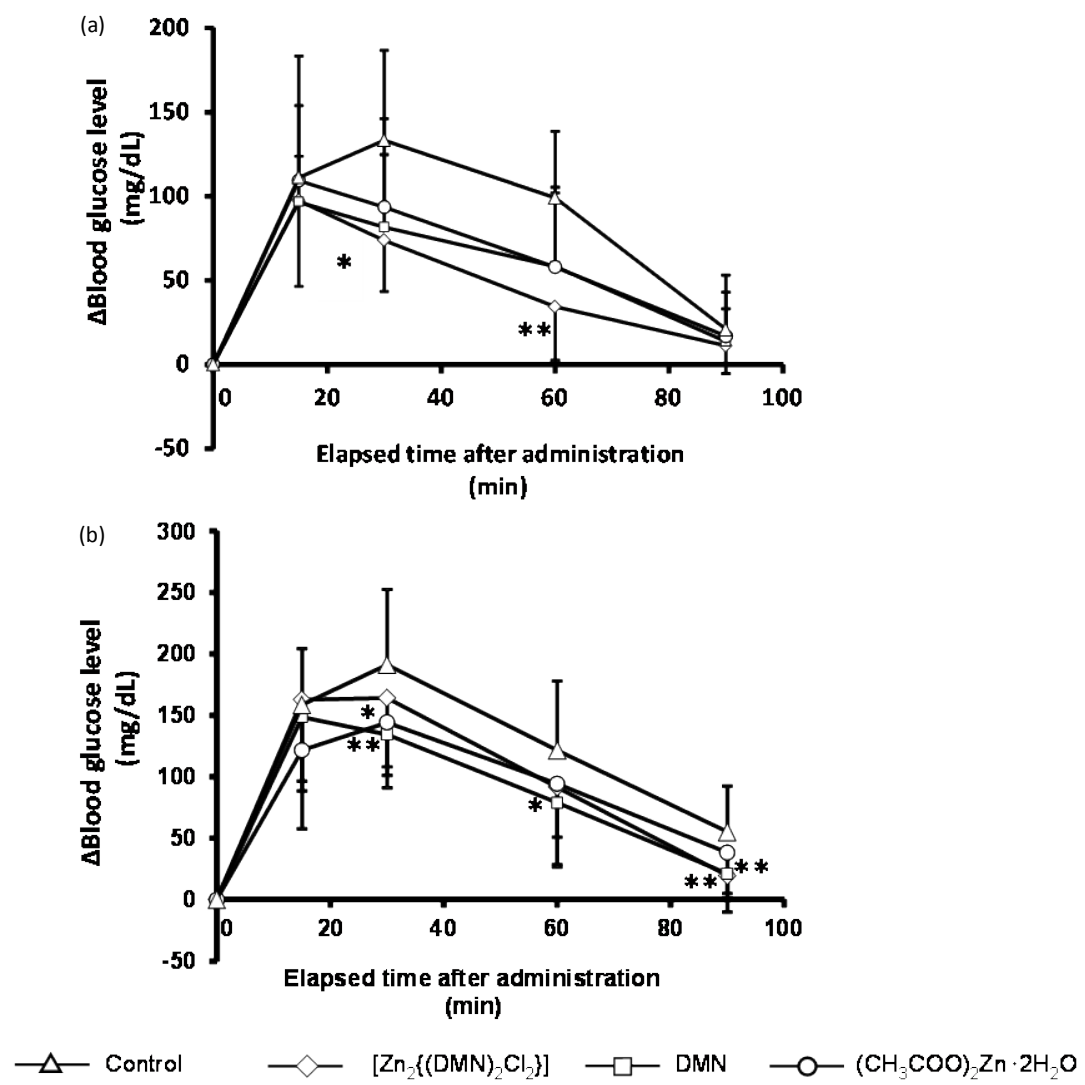

Figure 4. Inhibitory effects of $\left[\mathrm{Zn}_{2}\left\{(\mathrm{DMN})_{2} \mathrm{Cl}_{2}\right\}\right]$, DMN, and $\left(\mathrm{CH}_{3} \mathrm{COO}\right)_{2} \mathrm{Zn} \cdot 2 \mathrm{H}_{2} \mathrm{O}$ on the difference between the postprandial blood glucose level and the glucose level at $0 \mathrm{~min}$. Maltose (a) or glucose (b) were used as the substrates. 10- to 14-week-old male ddY mice were starved for $6 \mathrm{~h}$. Then the test samples $\left[\mathrm{Zn}_{2}\left\{(\mathrm{DMN})_{2} \mathrm{Cl}_{2}\right\}\right](15 \mathrm{mg} \mathrm{Zn} / \mathrm{kg}$ of body weight), $\left(\mathrm{CH}_{3} \mathrm{COO}\right)_{2} \mathrm{Zn} \cdot 2 \mathrm{H}_{2} \mathrm{O}$ (15 mg Zn/kg of body weight), DMN ( $0.056 \mathrm{mmol} / \mathrm{kg}$ body weight), and acacia solution (5\%; control) were orally administered to the mice. The substrate (maltose or glucose: $3 \mathrm{~g} / \mathrm{kg}$ of body weight) was orally administered 30 min later. Data are expressed as the mean \pm SD $(n=5-16)$. Significance: ${ }^{*} \mathrm{p}<0.05,{ }^{* *} \mathrm{p}<0.01$ vs. control. 

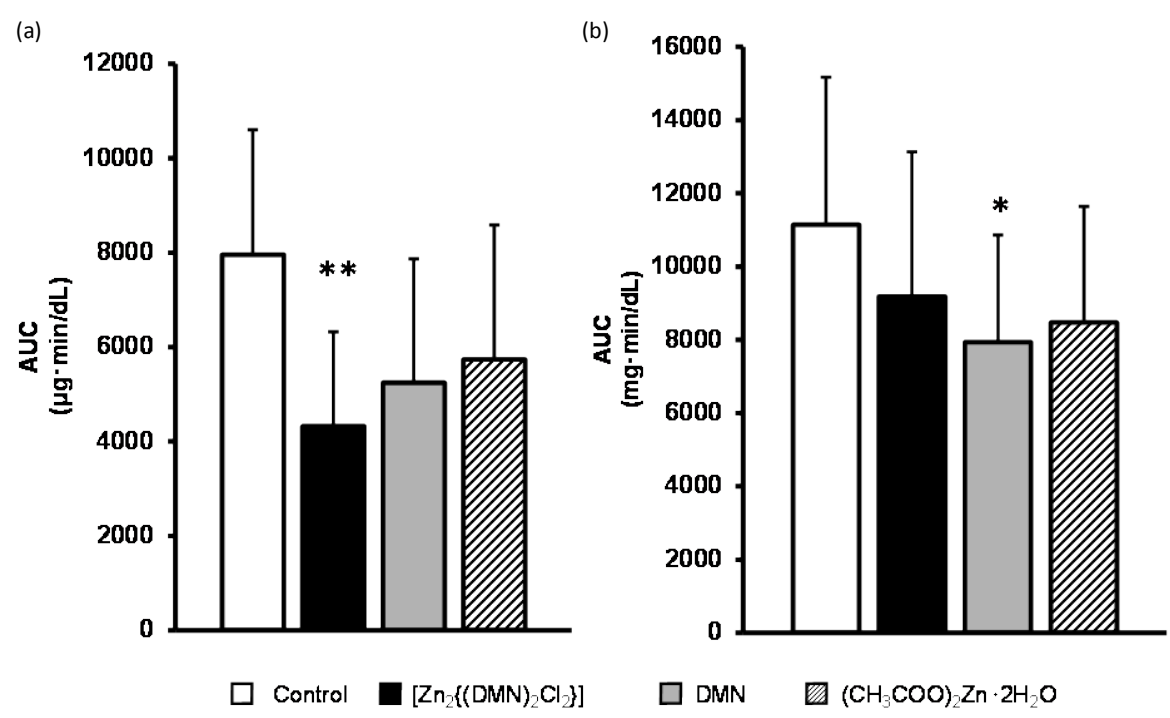

Figure 5. Effects of $\left[\mathrm{Zn}_{2}\left\{(\mathrm{DMN})_{2} \mathrm{Cl}_{2}\right\}\right]$, DMN, and $\left(\mathrm{CH}_{3} \mathrm{COO}\right)_{2} \mathrm{Zn} \cdot 2 \mathrm{H}_{2} \mathrm{O}$ on blood glucose concentrations after maltose (a) or glucose (b) loading in ddY mice. Data are represented as the mean $\pm \mathrm{SD}(\mathrm{n}=5-16)$. The $\mathrm{AUC}_{0}-90 \mathrm{~min}$ values were calculated as the area under the mean of the difference of blood glucose concentration-time curve for $90 \mathrm{~min}$ after maltose or glucose loading. Significance: ${ }^{*} \mathrm{p}<0.05,{ }^{* *} \mathrm{p}<0.01$ vs. Control.
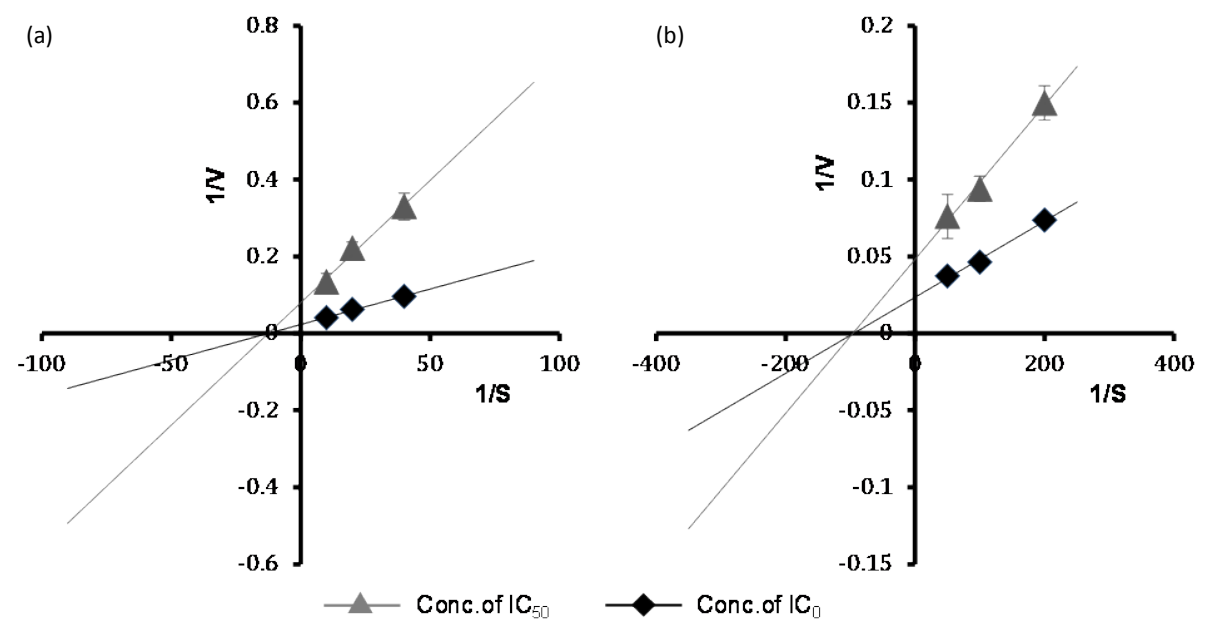

Figure 6. Lineweaver-Burk plots for the inhibition of $\alpha$-glucosidase by $\left[\mathrm{Zn}_{2}\left\{(\mathrm{DMN})_{2} \mathrm{Cl}_{2}\right\}\right]$ in yeast $\alpha$-glucosidase (a) and rat small intestinal $\alpha$-glucosidase (b).

\section{Discussion}

There have been many reports in recent years ascribing various biological activities to many metal ions or their complexes [27] [28]. The study of divalent alkaline earth, first-row transition metal, and Zn(II) ions have become particularly popular [5] [29]. In 2014, Kumar et al. reported that $\alpha$-glucosidase inhibitory activity of Schiff base complexes containing $\mathrm{Mn}, \mathrm{Co}, \mathrm{Ni}, \mathrm{Cu}, \mathrm{Sr}$, and $\mathrm{Cd}$ were more effective than that of the free Schiff base ligand [30]. Schiff base metal complexes have received a lot of attention from many researchers. In this study, we synthesized four Schiff base ligands and their Zn(II) complexes (Schemes 2-5). We chose Zn(II) from among many metals for this study because the Zn(II) ion was an essential trace element and Zn(II) compounds possessed a wide margin of safety. Figure 2 and Figure 3 showed that Zn(II) complexes derived from Schiff bases inhibited the $\alpha$-glucoidases from yeast and rat small intestine in in vitro study; however, the Schiff base ligands did not show activity by themselves. From these results, we could say that the $\alpha$-GI effect might be mainly caused by the $\mathrm{Zn}(\mathrm{II})$ in the complexes. In addition, the compounds that belonged to the "Schiff bases" did not necessarily 
Table 3. Stability constants of the Zn(II) complexes.

\begin{tabular}{cc}
\hline Compounds & Log $\mathrm{K}_{1}$ \\
{$\left[\mathrm{Zn}_{2}\left\{(\mathrm{DMN})_{2} \mathrm{Cl}_{2}\right\}\right]$} & Unknown \\
$\left(\mathrm{CH}_{3} \mathrm{COO}\right)_{2} \mathrm{Zn} \cdot 2 \mathrm{H}_{2} \mathrm{O}$ & $1.03[31]$ \\
Zinc gluconate & $1.70[31]$ \\
{$[\mathrm{N}-\mathrm{s} \beta-\mathrm{Zn}]$} & $4.50[32]$ \\
{$[\mathrm{N}-\mathrm{bsE}-\mathrm{Zn}]$} & $9.05[33]$ \\
{$[\mathrm{N}-\mathrm{bsP}-\mathrm{Zn}]$} & $13.3[34]$ \\
$\mathrm{Zn}-\mathrm{His}$ & $12.0[35]$ \\
$\mathrm{Zn}-\mathrm{Cys}$ & $18.2[35]$ \\
\hline
\end{tabular}

showed an $\alpha$-GI effect. The C-N double bond is considered an important factor for the $\alpha$-GI effect of the Schiff bases; however, we think that the $\alpha$-GI effect of several Schiff bases may be caused by factors other than their C-N double bond. [N-bsP-Zn] shows weaker effect than other Zn(II) complexes (Figure 2(a) and Figure 3(a)). As the reason for this result, we consider the possible involvement of the stability constant (Table 3). Moreover, cysteine and histidine residues play an important role in the active center of $\alpha$-glucosidase [36]. Thus, we expect that ligands which bind more strongly with $\mathrm{Zn}$ (II) ion than cysteine and histidine may prevent the $\alpha$-GI effect of the $\mathrm{Zn}$ (II) ion. In Figure 4(a) and Figure 5(a), DMN shows a $\alpha$-GI effect equivalent to the effect of zinc acetate against maltase in the in vivo study. Therefore, we think that the $\alpha$-GI effect of $\left[\mathrm{Zn}_{2}\left\{\left(\mathrm{DMN}_{2} \mathrm{Cl}_{2}\right\}\right]\right.$ against maltase may be caused by a synergic effect from the combination of the $\mathrm{Zn}(\mathrm{II})$ ion and this ligand.

In conclusion, Zn(II) ions and their complexes exhibited $\alpha$-GI effects in in vitro and in vivo studies. Additionally, although Schiff base ligands did not show a $\alpha$-GI effect in in vitro, DMN showed an anti-hyperglycemic effect in the glucose-loading test during the in vivo study. We considered that changing the ligand structures of $\mathrm{Zn}$ (II) complexes might result in synergic action between the metal ion and the ligand in producing a $\alpha$-GI effect. Finally, when searching for candidate compounds, we should look at their physical properties such as their stability constants, molecular weights, or lipid solubilities.

\section{Acknowledgements}

This study was supported financially in part by a grant from the Ministry of Education, Culture, Sports, Science, and Technology of Japan (MEXT) - Supported Program for the Strategic Research Foundation at Private Universities, 2012-2016 (S1201008). This study was also supported by a JSPS KAKENHI Grant Number 25460048.

\section{References}

[1] WHO Study Group (2006) Diabetes Mellitus. Fact Sheets, Geneva, 312.

[2] Shisheva, A., Gefel, D. and Shechter, Y. (1992) Insulin Like Effects of Zinc Ion in Vitro and in Vivo: Preferential Effects on Desensitized Adipocytes and Induction of Normoglycemia in Streptozocin-Induced Rats. Diabetes, 41, 982988. http://dx.doi.org/10.2337/diab.41.8.982

[3] Chen, M.D., Liou, S.J., Lin, P. ., Yang, V.C., Alexander, P.S. and Lin, W.H. (1998) Effects of Zinc Supplementation on the Plasma Glucose Level and Insulin Activity in Genetically Obese (ob/ob) Mice. Biological Trace Element Research, 61, 303-311. http://dx.doi.org/10.1007/BF02789090

[4] Wang, Y., Ma, L., Li, Z., Du, Z., Liu, Z., Qin, J., Wang, X., Huang, Z., Gu, L. and Chen, A.S.C. (2004) Synergetic Inhibition of Metal Ions and Genistein on $\alpha$-Glucosidase. FEBS Letters, 576, 46-50. http://dx.doi.org/10.1016/j.febslet.2004.08.059

[5] Yoshikawa, Y., Hirata, R., Yasui, H., Hattori, M. and Sakurai, H. (2010) Inhibitory Effect of $\mathrm{CuSO}_{4}$ on $\alpha$-Glucosidase Activity in ddY Mice. Metallomics, 2, 67-73. http://dx.doi.org/10.1039/B906709D

[6] Yoshikawa, Y., Kawabe, K., Tadokoro, M., Suzuki, Y., Yanagihara, N., Nakayama, A., Sakurai, H. and Kojima, Y. (2002) New Zinc (II) Complexes with Tetradentate Amino Acid Derivatives: Structure Characterization, Solution Chemistry, and in Vitro Insulinomimetic Activity. Bulletin of the Chemical Society of Japan, 75, 2423-2432. http://dx.doi.org/10.1246/bcsj.75.2423 
[7] Adachi, Y., Yoshida, J., Kodera, Y., Kiss, T., Jakusch, T., Enyedy, E.A., Yoshikawa, Y. and Sakurai, H. (2006) Oral Administration of a Zinc Complex Improves Type 2 Diabetes and Metabolic Syndromes. Biochemical and Biophysical Research Communications, 351, 165-170. http://dx.doi.org/10.1016/j.bbrc.2006.10.014

[8] Kawarada, H., Yoshikawa, Y., Yasui, H., Kuwahara, S., Habata, Y. and Saitom R. (2011) Synthesis and in Vitro Insulin-Mimetic Activities of Zinc (II) Complexes of Ethyl 2, 5-Dihydro-4-hydroxy-5-oxo-1 H-Pyrrole-3-carboxylates. Metallomics, 3, 675-679. http://dx.doi.org/10.1039/c1mt00009h

[9] Misra, S., Pandeya, K.B., Tiwari, A.K., Ali, A.Z., Saradamani, T., Agawane, S.B. and Madhusudana, K. (2011) AlphaGlucosidase Inhibitory and DPPH Free Radical Scavenging Activity of 5-Bromosalicylaldehyde and Schiff Bases. Medicinal Chemistry Research, 20, 1431-1437. http://dx.doi.org/10.1007/s00044-010-9377-3

[10] Aslam, M., Anis, I., Afza, N., Hussain, A., Iqbal, L., Iqbal, J., Ilyas, Z., Iqbal, S., Chaudhry, A.H. and Niaz, M. (2012) Structure-Activity Relationship Study: Synthesis, Characterization and Biological Investigation of Schiff Bases Derived from 2-Aminophenol and 4-Haloacetophenones. International Journal of Current Pharmaceutical Research, 4, 42-46.

[11] Sridhar, S.K. and Ramesh, A. (2001) Synthesis and Pharmacological Activities of Hydrazones, Schiff and Mannich Bases of Isatin Derivatives. Biological and Pharmaceutical Bulletin, 24, 1149-1152. http://dx.doi.org/10.1248/bpb.24.1149

[12] Vazzana, I., Terranova, E., Mattioli, F. and Sparatore, F. (2004) Aromatic Schiff Bases and 2,3-Disubstituted-1,3-thiazolidin-4-one Derivatives as Anti-Inflammatory Agents. ARKIVOC, 5, 364-374.

[13] Natarajan, U., Kaliappan, I. and Singh, N.K. (2010) A Facile Design and Efficient Synthesis of Schiff Bases of Tetrazolo [1,5- $\alpha$ ] Quinoxalines as Potential Anti-Inflammatory and Anti-Microbial Agents. Der Pharma Chemica, 2, 159167.

[14] More, P.G., Bhalvankar, R.B. and Pattar, S.C. (2001) Synthesis and Biological Activity of Schiff Bases of Aminothiazoles. Journal of the Indian Chemical Society, 78, 474-475.

[15] Rajendran, S.P. and Karvembu, R. (2002) Synthesis and Antifungal Activities of Schiff Bases Derived from 3-Amino2H-pyrano [2,3-b] Quinolin-2-Ones. Indian Journal of Chemistry, 41B, 222-224. http://dx.doi.org/10.1002/chin.200219139

[16] Ugras, H.I., Basaran, I., Kilic, T. and Cakir, U. (2006) Synthesis, Complexation and Antifungal, Antibacterial Activity Studies of a New Macrocyclic Schiff Base. Journal of Heterocyclic Chemistry, 43, 1679-1684. http://dx.doi.org/10.1002/jhet.5570430639

[17] Sriram, D., Yogeeswari, P. and Gopal, G. (2005) Synthesis, Anti-HIV and Antitubercular Activities of Lamivudineprodrugs. European Journal of Medicinal Chemistry, 40, 1373-1376. http://dx.doi.org/10.1016/j.ejmech.2005.07.006

[18] Saravanan, G., Pannerselvam, P. and Prakash, C.R. (2010) Synthesis and Anti-Microbial Screening of Novel Schiff Bases of 3-Amino-2-methyl Quinazolin-4-(3H)-one. International Journal of Research in Pharmaceutical Sciences, 1, 320-325. http://dx.doi.org/10.4103/0110-5558.72426

[19] Pandey, S. and Srivastava, R.S. (2011) Synthesis and Characterization of Some Heterocyclic Schiff Bases: Potential Anticonvulsant Agents. Medicinal Chemistry Research, 20, 1091-1101. http://dx.doi.org/10.1007/s00044-010-9441-z

[20] Kuz’min, V.E., Lozitsky, V.P., Kamalov, G.L., Lozitskaya, R.N., Zheltvay, A.I., Fedtchouk, A.S. and Kryzhanovsky, D.N. (2000) Analysis of the Structure-Anticancer Activity Relationship in a Set of Schiff Bases of Macrocyclic 2,6-Bis(2- and 4-formylaryloxymethyl)pyridines. Acta Biochimica Polonica, 47, 867-875.

[21] Vanco, J., Marek, J., Trávnícek, Z., Racanská, E., Muselík, J. and Svajlenová, O. (2008) Synthesis, Structural Characterization, Antiradical and Antidiabetic Activities of Copper(II) and Zinc(II) Schiff Base Complexes Derived from Salicylaldehyde and Beta-Alanine. Journal of Inorganic Chemistry, 102, 595-605.

[22] You, Z.L., Shi, D.H. and Zhu, H.L. (2006) The Inhibition of Xanthine Oxidase by the Schiff Base Zinc(II) Complex. Inorganic Chemistry Communications, 9, 642-644. http://dx.doi.org/10.1016/j.inoche.2006.03.023

[23] Dahlqvist, A. (1964) Method for Assay of Intestinal Disaccharidases. Analytical Biochemistry, 7, 18-25. http://dx.doi.org/10.1016/0003-2697(64)90115-0

[24] Hanamura, T., Mayama, C., Aoki, H., Nirayama, Y. and Shimizu, M. (2006) Antihyperglycemic Effect of Polyphenols from Acerola (Malpighia emarginata DC.) Fruit. Bioscience, Biotechnology, and Biochemistry, 70, 1813-1820. http://dx.doi.org/10.1271/bbb.50592

[25] Suresh Babu, K., Tiwari, A.K., Srinivas, P.V., Ali, A.Z., China Raju, B. and Rao, J.M. (2004) Yeast and Mammalian $\alpha$-Glucosidase Inhibitory Constituents from Himalayan Rhubarb Rheum emodi Wall.ex Meisson. Bioorganic \& Medicinal Chemistry Letters, 14, 3841-3845. http://dx.doi.org/10.1016/j.bmcl.2004.04.062

[26] Oku, T., Yamada, M., Nakamura, M., Sadamori, N. and Nakamura, S. (2006) Inhibitory Effects of Extractives from Leaves of Morus Alba on Human and Rat Small Intestinal Disaccharidase Activity. British Journal of Nutrition, 95, 933-938. http://dx.doi.org/10.1079/BJN20061746 
[27] Efthimiadou, E.K., Psomas, G., Sanakis, Y., Katsaros, N. and Karaliota, A. (2007) Metal Complexes with the Quinolone Antibacterial Agent N-Propyl-Norfloxacin: Synthesis, Structure and Bioactivity. Journal of Inorganic Biochemistry, 101, 525-535. http://dx.doi.org/10.1016/j.jinorgbio.2006.11.020

[28] Hoffman, A.E., DeStefano, M., Shoen, C., Gopinath, K., Warner, D.F., Cynamon, M. and Doyle, R.P. (2013) Co(II) and $\mathrm{Cu}(\mathrm{II})$ Pyrophosphate Complexes Have Selectivity and Potency against Mycobacteria Including Mycobacterium Tuberculosis. European Journal of Medicinal Chemistry, 70, 589-593. http://dx.doi.org/10.1016/j.ejmech.2013.10.044

[29] Xu, X., Zhang, L., Luo, Z., Shen, D., Wu, H., Peng, L., Song, J. and Zhang, Y. (2010) Metal Ions Binding to NAD-Glycohydrolase from the Venom of Agkistrodon acutus: Regulation of Multicatalytic Activity. Metallomics, 2, 480-489. http://dx.doi.org/10.1039/c0mt00017e

[30] Kumar Naik, K.H., Selvaraj, S. and Naik, N. (2014) Metal Complexes of ONO Donor Schiff Base Ligand as a New Class of Bioactive Compounds; Synthesis, Characterization and Biological Evolution. Spectrochim. Spectrochimica Acta Part A: Molecular and Biomolecular Spectroscopy, 131, 599-605. http://dx.doi.org/10.1016/j.saa.2014.03.038

[31] Young, A., Jonski, G. and Rölla, G. (2002) The Oral Anti-Volatile Sulphur Compound Effects of Zinc Salts and Their Stability Constants. European Journal of Oral Sciences, 110, 31-34. http://dx.doi.org/10.1034/j.1600-0722.2002.00157.x

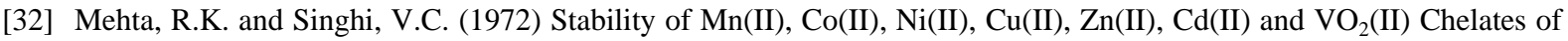
$\mathrm{N}$-Salicylidene- $\beta$-alanine. Indian Journal of Chemistry, 10, 233-234.

[33] Rath, N., Jena, S., Chakravortty, V. and Dash, K.C. (1998) Stability Constants of Cobalt-, Nickel- and Zinc(II) Complexes of Some Tetradentate Imine-Phenol Ligands. Journal of the Indian Chemical Society, 75, 160-161.

[34] Hernández-Molina, R., Mederos, A., Gili, P., Dominguez, S. and Nùñez, P. (1997) Complexation Equilibria of N,N’-oPhenylenebis(salicylideneimine). Polyhedron, 16, 4191-4196. http://dx.doi.org/10.1016/S0277-5387(97)00267-2

[35] Sillén, L.G. and Martell, A.E. (1971) Stability Constants of Metal-Ion Complexes. Supplement No. 1, The Chemical Society, London, Special Publ. No. 25.

[36] Lodge, J.A., Maier, T., Liebl, W., Hoffmann, V. and Sträter, N. (2003) Crystal Structure of Thermotoga maritima $\alpha$-Glucosidase AglA Defines a New Clan of NAD ${ }^{+}$-Dependent Glycosidases. The Journal of Biological Chemistry, 278, 19151-19158. http://dx.doi.org/10.1074/jbc.M211626200 